\title{
The sectoral-regional structure of the wages in Mexico
}

\author{
La estructura sectorial-regional de los salarios en México
}

\author{
Rolando I. Valdez and Verónica Sobrevilla \\ Universidad Autónoma de Tamaulipas, México \\ Universidad Autónoma de Baja California, México
}

Abstract

The present study analyses the sectoral and the regional structure of the wages in Mexico. We exploit a pooled data model with information from the National Occupation and Employment Survey (ENOE) from 2005 to 2018. The results show generalized discrimination against women in all economic activities and regions of the country. The education return on wage differentiates among economic activities, and overall, it is more profitable for women. In professional services, an additional year of education increases 8.4 per cent the salary; in restaurants and lodging services, this return is 3.9 per cent. This study also shows that education is more profitable in the northeast than in other parts of the country. Wages in agriculture in the north double the wages in agriculture in the south. One of the main implications of this study is that education is a crucial instrument for narrowing the gap between women's and men's wages.

Keywords: Wage, inequality, regions, economic activities.

\section{Resumen}

En el presente estudio es analizada la estructura sectorial y regional de los salarios en México. Es llevado a cabo un modelo de datos agrupados con información de la Encuesta Nacional de Ocupación y Empleo (ENOE) de 2005 a 2018. Los resultados muestran una discriminación generalizada en contra de las mujeres en todas las actividades económicas y en todas las regiones del país. El rendimiento de la educación en los salarios se encuentra diferenciado entre las actividades económicas, y en general es más beneficiosa para las mujeres. En los servicios profesionales un año adicional de educación conduce a un aumento de 8.4 por ciento del salario, en restaurantes y servicios de alojamiento este rendimiento es de 3.9 por ciento. Este estudio también muestra que la educación es más redituable en el noreste que en el resto del país. Los salarios en la agricultura en el norte duplican a los salarios en la agricultura del sur. Una de las principales implicaciones del presente estudio es que la educación es un instrumento clave para reducir las diferencias en los salarios entre mujeres y hombres.

Palabras clave: Salarios, desigualdad, regiones, actividades económicas. 


\section{INTRODUCTION}

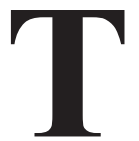

he wage is a broad topic in the economic literature. It has been studied several times from many perspectives. It is an important issue due to those indicators like productivity, welfare, inequality, among others, are linked with earnings by the job. Economic activities require different workers to take advantage of their skills and capabilities; this heterogeneity drives to a productivity rates difference, which should explain that some workers earn more than others.

The geographic location of the economic activity relates to the specialization. Some activities develop in the territory due to the availability of natural resources, like the oil industry, mining, or agriculture. Moreover, some economic activities arise in territories where there are highly educated workers; thus, the region is also an explanatory component of the wage.

In a country like Mexico, with a vast territory extension, and natural diversity, there is space to develop many economic activities. Consequently, there are many determinants and differences in the wages in Mexico to account.

After signing the North America Trade Agreement (NAFTA), the relocation of the economic activity spread out from Mexico City to the rest of the country, generating specialized territories in specific sectors (Rodríguez, 2018). Along with territory specialization arises the interest to know the structure of the wages in Mexico by economic activity and region because the increase of the wage inequality in the world is due to regional or sectoral phenomena (Aláez, Longás and Ullibarri, 2003; Palacio Morena and Simón Pérez, 2004; Ahamdanech Zarco, García Pérez and Simón Pérez, 2001; Castro Lugo and Morales Sandoval, 2011; Groot, de Groot and Smit, 2014).

In this document, we examine the sectoral and regional structure of wages in Mexico. The present study aims to analyze the main dimensions of the composition of the salaries in Mexico beyond the classic analysis that includes components like education experience and tenure; among others, we propose to include sectoral and regional features in the study. These additional factors allow extending the understanding of the differences in wages in the country. The present analysis might be helpful for labor economists interested in the study of wage difference, wage discrimination, regional wages, among others. This inquiry might be beneficial for policymakers seeking elements to reduce the differences in income gaps and regional disparities. 
The organization of the present document splits into four sections added to the current; the first one contains the literature review, consists of a collection of inquiries that deal with the topic of wages from many perspectives: individual, firm, sectoral, regional, and others. The second section contains the methodology and data; we describe the variables used in the analysis and the econometric specification, and the estimation method. In the third section, we perform the empirical analysis, where we show the results from the econometric exercise and a discussion of the results. The last part corresponds with the concluding remarks derived from the results and literature review and some public policy recommendations related to diminishing the wage difference in Mexico.

\section{LITERATURE REVIEW}

The first studies that deal with wages are based on the characteristics of workers as factors that explain the difference in wages. Juhn, Murphy and Pierce (1993) carry out an analysis from 1963 to 1989 that describes the increase of the general inequality; they decompose the wages in components explained by the observable differences among workers like age and education and by factors into these variables. They also find that employment has shifted towards industries and occupations that demand more skilled workers, even in rising skill premiums. Its interpretation is that a large part of the increase in wage differences among men obeys higher returns in the years of schooling and the years of experience in the labor market.

The education return on wages is also analyzed by Buchinsky (1994), who examines the changes in the returns of skills, particularly education and experience, at different points of the wage distribution. This author follows the Mincer's (1974) equation for wages and the quantile regression from Koenker and Bassett (1978). His results suggest that the return of schooling and experience differ among the quantiles of the wages distribution, but their patterns of change are similar. There are also significant differences in wage inequality between different skill groups.

Aláez, Longás y Ullibarri (2003) analyze the wage differences considering Spain's sectoral and regional structure. Their results describe a dual system to determine wages in that country, such that sectors and regions with high productivity link with high salaries and high living costs. In contrast, industries and areas with low productivity levels are limited for a bound in wages.

Palacio and Simón (2004) analyze the determinants of salaries in the Spanish job market. They consider supply and demand factors in the analy- 
sis. Their results show wage differences between workers with the same skills that work in a different company and the firm's location. Larraz and Herrera (2016) analyze the determinants of wage concentration in Spain in the same line. Their results show that regional differences, company type, and worker characteristics increase wage inequality Zarco, García y Simón (2011).

Madariaga, Martori, and Oller (2012) study the spatial distribution of wages in the Barcelona metropolitan area through a spatial autocorrelation analysis. They implement a method that considers a smaller spatial unit as a census section to carry out the investigation. Their results are not entirely different from the studies cited above; they find a generalized increase of wage inequality in the metropolitan area of Barcelona; this increment follows a spatial pattern.

Groot, De Groot and Smit (2014) identify the nature and causes of wage differences in the Netherlands. These authors consider geographical and economic dimensions through the Mincer equation (1974) and the Marshall-Arrow-Romer effect (MAR) for externalities. Their results confirm that wages are considerably higher in the urbanized area of Randstad than in the rest of the Netherlands. The total size of the regional labor market has a statistically significant and positive effect on wages; even though this explains a relatively small part of the spatial residual, a positive sign is evidence against the economic theory about determining the wages.

Katz and Kearney (2008) reevaluate the traditional and revisionist explanations for changes in the U.S. wage inequality over the last four decades, the "revisionist" which determined that the increase in the wage inequality in the U.S. in the 1980s was due to an "episodic" event rather than a secular phenomenon. The analysis covers the period 1963-2005. They find that changes in "price" and changes in income dispersion within narrowly defined demographic groups (age, sex, education, and others) remain a vital force in the evolution of residual wage inequality in both up as the bottom of the tail. The roughly parallel movement of earnings and employment growth in each decade suggests that demand forces have played a key role in shaping changes in the wage structure during the rising inequality in the 1980s and the further polarization. These patterns are partly explained by a newer version of the Skill-biased Technique Change (SBTC) hypothesis, where technological information complements highly educated-dedicated workers to abstract tasks, substitutes for moderately educated workers performing routine tasks, and has a less impact on low-skilled workers performing manual tasks. 
Antonczyk, DeLeire and Fitzenberger (2010) provide a comparative analysis of the increase in wage inequality in the U.S. and Germany, focusing on the role of cohort effects. These authors find that wage inequality is growing throughout the life cycle in both countries and for all educational groups, with one exception. For low education workers in Germany, there is a diminishing wage inequality throughout the life cycle. The changing age structure of the labor force has important implications for trends in wage inequality in both the U.S. and Germany, but the increase in skill premiums is much more significant in the U.S.

The interest of wage studies in Mexico is chiefly in NAFTA's role on the salary changes due to the implications that an agreement like that represents. Airola and Juhn (2005) analyze wages and employment in Mexico after trade liberalization and domestic reforms. Their results show that after a sharp increase in inequality during the first decade of reforms, 1984-1994, overall wage inequality decreased, and education premiums stabilized in Mexico. During 1994-1995, the Mexican economy suffered a severe macroeconomic crisis that had a more adverse impact on skilled than unskilled workers.

The wage inequality arose in Mexico in the last years driven by the economic liberalization because the well-paid activities relate to the external sector (Plascencia López, 2009). Plascencia (2009) studies the wage inequality evolution and its relationship with other variables linked with the economic liberalization process through the Kuznets' (1995) methodology to correlate economic inequality with income. The results indicate that wage inequality of cities increased after the late 1994 crises, when a dynamic and competitive sector, represented by big enterprises, which benefited from devaluation, increased their income from exports. In contrast, the rest of the population fell in a depressed intern market, whom recessive characteristics were reflected on the loss of real purchasing power.

Popli (2011) analyzes the impact of changes in human capital on wage inequality in Mexico, particularly the effect of a higher supply of skilled labor on wage inequality. The focus of this paper is on three years 1984, 1994, and 2000. The findings suggest that education plays a vital role in the dispersion of Mexican workers' wages and changes in this dispersion over time. The results document the contribution of education in wage dispersion in Mexico and reveal that both the changing returns to education and the changing educational attainments are essential factors in increasing and decreasing wage inequality over the past two decades. 
Rodríguez, Huesca y Camberos (2011) analyze the effect of technological change in the occupational structure, wages, and workers' inequality of the Mexican regions. Their results show that higher wage differences are found between northern-bound and southern areas, where high technology firms prevail in the first and the traditional ones in the last.

Castro and Morales (2011) study the regional wage inequality in Mexico from 1994 to 2003 where they identify the factors that impact it through the "second moment" method, proposed by Blau and Kahn (1992) and adapted by Monastiriotis (2003), based on the wage disparities analysis, which considers the logarithm variance of real wage per hour. Their results suggest diminishing the total gap from 1995 and the trend to a convergence of labor income into the regions, while the differences between them increase along with factors endowment. Also, they show that inequality between regions is more relevant than within them.

Varela and Urciaga (2012) examine the determinants of head-household wages in Mexico from a labor perspective that considers human capital, economic activity sector, firm size, territory, gender, and labor contract elements. Their results corroborate that human capital endowment is a variable that explains the head-household wage. On the demand side, they observe that firm size impacts wages as well. The head-household that signs a contract expects higher pay than workers without it. Also, the territorial and social factors, firm size, and economic activity are relevant in wage differences of head-household in Mexico.

Cardoso (2016) inquiries how the potential market explains the wage differences among manufacturing workers in the Mexican states; his results show a positive relationship between productive specialization and wages. Workers take advantage due to geographic locations where economic activity agglomerates. Also, he finds that wages of informal workers are less elastic to changes in potential market if they are compared with formal workers, even, they gain from externalities driven from foreign firms. He suggests that up to 10.7 per cent of the wage differences between north-border workers and southern workers are due to economic geography. This effect is lower for informal workers, and it duplicates for formal ones.

\section{Methodology AND DATA}

The goal of the present section is to release a model to explain the differences between wages. The hypothesis is that, after controlling issues about productivity labor, such as age, education, experience (Mincer, 
1974), there are other components to explain differences in wages. Studies from Juhn, Murphy and Pierce (1993); Buchinsky (1994); Airola and Juhn (2005); Cortez (2005); Katz and Kearney (2008); Cabrera, Mungaray, Varela and Hernández (2008); Varela, Ocegueda, Castillo and Huber (2010); Popli (2011) corroborate Mincer's findings, where there is evidence that age, education, and experience explain how wages are determined.

The last factors that explain wage differences are related to productivity; however, these ignore some aspects related to the intensity and quality of the job. Farmers, engineers, and accountants might share the same age, education, and experience; nevertheless, their activities demand specific skills that explain differences between their earnings. Therefore, the economic sector where workers are employed is an additional element to consider for the analysis, due to allows to control more aspects related to the workers' ability and economic structure as well (Carrillo-Huerta and Vázquez Mateos, 2005; Castro Lugo and Morales Sandoval, 2011; Varela Llamas and Urciaga García, 2012; Groot, de Groot and Smit, 2014.

Moreover, the economic structure is spatially distributed unequally in the country; many regions specialize in different economic activities and dynamics. The main financial center in the country is in Mexico City. At the same time, the aerospace industry chiefly locates in Queretaro; the tourism industry is solid in Quintana Roo and Baja California Sur, and so on. The assumption about the economic activity's skill requirements has spatial components; this implies that the wage might vary across cities, states, regions, or any other territorial aggregation.

Other factors explain wages that we must include in the model. These relate to characteristics of the worker, such as tenure in the current job. Even though age allows to control the experience, because older people owe more experience, tenure not necessarily relates to age but with wages. Most jobs pay a prime over the years worked into the firm. So that, workers with the same skills and jobs may receive different wages due to tenure. Workers married should differ on non-married due to the responsibilities gained with a partner. Married workers even could work a part-time job because the partner is full-time employed and so on. Finally, gender is an element that allows controlling some discrimination issues against women or men.

Based on the last, the table below contains the variables that allow explaining wage differences (Table 1). 
Table 1: Description of the variables used in the empirical analysis

\begin{tabular}{ll}
\hline Variable & \multicolumn{1}{c}{ Description } \\
\hline Wage & Wage accumulated by three months \\
Female & Age in years \\
Married & Dummy variable ( $=1$ if the worker is a woman) \\
Education & Dummy variable (=1 if the worker is married) \\
Tenure & Years of formal education in years \\
Sector & Years of tenure in the current job \\
Region & The economic sector where the worker is employed \\
\hline
\end{tabular}

Source: Own elaboration.

The econometric specification exploits a pooled data structure, which is as follows:

$$
\mathrm{y}_{\mathrm{it}}=\beta_{0}+\beta_{\mathrm{i}} \mathrm{x}_{\mathrm{it}}+\mathrm{a}_{\mathrm{i}}+\mathrm{d}_{\mathrm{t}}+\varepsilon_{\mathrm{it}}
$$

Where is a dependent variable for i-individuals and t-periods, whereas is a vector of independent variables. The component $a_{\mathrm{i}}$ is the unobservable heterogeneity between individuals, which is constant over time, $d_{\mathrm{t}}$ is a factor that impacts over all individuals in the same direction associated with a change in time. Finally, is an error component that either varies for individuals as well as time.

The econometric specification splits into three components. The first one corresponds to characteristics from individuals, such as age, marital status, and sex, along with their interaction terms. We decided to include these interactions because they increase the analysis ability. For instance, we assume that wages vary between females and males, but between female married and females non-married and males married and males non-married. Moreover, the interaction terms allow comparing female non-married with male married, female married with male married, and female married with male non-married.

The second component contains characteristics about productivity, such as years of schooling and tenure in the current job. These characteristics are independent of those found in the first component; however, we are interested in computing the education return by sex; this implies interacting the variable sex with the education, which helps to control whether years of education report differentiated returns on wages. 
The third component includes the two key elements of the current inquiry; these are the sector and the region variables and their respective interactions. The interactions of these elements cross over the characteristics of individuals.

The three components of the specification summarise in the following Table 2:

Table 2: Components of the econometric specification

\begin{tabular}{lll}
\hline Component & Variables & Interactions \\
\hline \multirow{2}{*}{ Characteristics } & $\begin{array}{l}\text { Age, } \\
(\text { Age })^{2},\end{array}$ & \\
Female, & Female*Married \\
Married & $\begin{array}{l}\text { Education } \\
\text { Tenure }\end{array}$ & Education*Female \\
& & $\begin{array}{l}\text { Sector*Female } \\
\text { Sector*Education } \\
\text { Region*Female } \\
\text { Region*Education } \\
\text { Region*Sector }\end{array}$ \\
\hline
\end{tabular}

Source: Own elaboration.

The functional form is specified with the dependent variable (Wage) in logarithm form, such as literature suggests. At the same time, we introduce the explanatory variables in levels. The econometric specification is as follows.

$$
\log \left(\text { WAGE }_{\mathrm{t}}\right)=\alpha_{0}+\beta \mathrm{CHAR}_{\mathrm{t}}+\gamma \mathrm{PROD}_{\mathrm{t}}+\delta \mathrm{SECREG}_{\mathrm{t}}+\mathrm{a}_{\mathrm{i}}+\varepsilon_{\mathrm{it}}
$$

The data for the current inquiry comes from the National Survey of Occupation and Employment (ENOE for its acronym in Spanish), provided by the National Institute of Statistics Informatics and Geography (INEGI for its acronym in Spanish). The ENOE is a composite of basic and extended surveys; each adds information of some characteristics of workers and jobs. The present investigation considers the extended survey because it provides more information than the basic one, plus it releases information about a second job of the worker. So that, the wage variable is the sum of all earnings of the worker. The ENOE provides information quarterly; however, we consider only one quarter per year for this study due to the extended survey is released once a year. 
The economic sector considers three categories: primary, secondary, and tertiary. The first one contains activities like agriculture, forestry, fishing, and hunting. The secondary sector includes mining, generation, and distribution of energy, supply of water and gas, and manufacturing. The tertiary sector refers to commerce, transportation, services, education, among others.

Now, we turn on the data. Table 3 shows the summary statistics of the continuous variables, such as wage, age, education, and tenure. Notice that these variables are aggregated over the years, from 2005 to 2018.

The average wage in the whole period is $\$ 7,054.94$; moreover, the standard deviation is higher than the mean due to the minimum and maximum values, which are substantially distant from each other. It is more convenient to take the median in these cases, found at the percentile 50 of the distribution; this vanishes the significant differences across observations. $\$ 5,444.76$ is a more accurate value for the wage over the whole period (Table 3).

Table 3: Summary statistics of the variables

\begin{tabular}{lrccc}
\hline & \multicolumn{1}{c}{ Wage } & Age & Education & Tenure \\
\hline Mean & $\$ 7,054.94$ & 38 & 10 & 8 \\
Median & $\$ 5,444.76$ & 37 & 9 & 4 \\
Minimum & $\$ 1.11$ & 12 & 0 & 0 \\
Maximum & $\$ 1,708,522.13$ & 98 & 24 & 87 \\
Std. Deviation & $\$ 8,359.93$ & 14 & 5 & 9 \\
$\mathrm{~N}$ & $1^{\prime} 815,247$ & $1^{\prime} 815,247$ & $1^{\prime}, 812,718$ & $1^{\prime} 811,805$ \\
\hline
\end{tabular}

Source: Own elaboration with data from INEGI, 2005-2018.

In Table 4 are shown summary statistics about gender and marital status. The mean wage for a female is $\$ 5,910$, whereas for a male is $\$ 7,774$. They share the same average age but not education. The female has ten years of schooling on average, and the male has nine years, regarding tenure, male own nine years on average and female, seven. The difference between the characteristics is pretty similar between the two sexes; however, female wages represent 76 per cent of the male wage. 
Table 4: Summary statistics by sex and marital status

\begin{tabular}{lcccc}
\hline & Wage & Age & Education & Tenure \\
\hline Sex & & & & \\
Male & $\$ 7,774.00$ & 38 & 9 & 9 \\
Female & $\$ 5,910.00$ & 38 & 10 & 7 \\
Marital status & & & & \\
Non-Married & $\$ 5,972.00$ & 33 & 10 & 6 \\
Married & $\$ 7,700.00$ & 41 & 9 & 9 \\
\hline
\end{tabular}

Source: Own elaboration with data from INEGI, 2005-2018.

Married workers earn 28 per cent more than non-married workers. As expected, the average age of married workers is 41 years, whereas the rest is 33. Married workers have the same years of education and tenure, nine years. For non-married workers, these statistics are ten and six, respectively. Thus, marriage is a crucial element that explains wage differences.

Table 5 shows summary statistics by economic activity. The tertiary sector is the best paid in Mexico, with an average wage of $\$ 7,421$. The lowest-paid activity is found in the primary sector and the minimum average of years of education but with the highest average years of tenure.

Table 5: Summary statistics by economic activity

\begin{tabular}{lcccc}
\hline Economic Activity & Wage & Age & Years of education & Tenure \\
\hline NA & $\$ 3,875$ & 32 & 8 & 3 \\
Agriculture & $\$ 4,044$ & 41 & 6 & 14 \\
Mining and elect & $\$ 13,571$ & 39 & 11 & 11 \\
Manufacturing & $\$ 6,492$ & 36 & 9 & 7 \\
Construction & $\$ 7,562$ & 37 & 8 & 8 \\
Commerce & $\$ 6,031$ & 37 & 9 & 6 \\
Restaurants and & $\$ 5,711$ & 36 & 9 & 5 \\
Transport and co & $\$ 8,615$ & 39 & 10 & 8 \\
Professional Ser & $\$ 8,903$ & 37 & 12 & 6 \\
Social Services & $\$ 10,713$ & 39 & 14 & 12 \\
Misc Services & $\$ 5,160$ & 39 & 8 & 7 \\
Government & $\$ 10,531$ & 40 & 12 & 11 \\
\hline
\end{tabular}

Source: Own elaboration with data from INEGI, 2005-2018.. 
Before releasing the summary statistics by region, we must choose one. We identify three different regionalizations in the literature: 1) That made by Bassols (1992), 2) The regionalization by Esquivel (1999), and 3) The socioeconomic regionalization by the INEGI.

To avoid an arbitrary selection on these three options, we performed a regression of the equation (2) through an OLS estimation to determine the region which provides the best estimators. The best fit comes from the regions defined by Bassols (1992), which we describe below Table 6).

Table 6: Distribution of the states in socioeconomic regions

\begin{tabular}{|c|c|}
\hline Region & State \\
\hline Northwest & $\begin{array}{l}\text { Baja California, Baja California Sur, Sonora, Sinaloa, } \\
\text { Nayarit. }\end{array}$ \\
\hline North & $\begin{array}{l}\text { Chihuahua, Coahuila, Durango, Zacatecas, } \\
\text { San Luis Potosí. }\end{array}$ \\
\hline Northeast & Nuevo León, Tamaulipas. \\
\hline Center-West & $\begin{array}{l}\text { Jalisco, Aguascalientes, Colima, Michoacán, } \\
\text { Guanajuato. }\end{array}$ \\
\hline Center-East & $\begin{array}{l}\text { Querétaro, México, Ciudad de México, Morelos, } \\
\text { Hidalgo, Tlaxcala, Puebla. }\end{array}$ \\
\hline South & Chiapas, Guerrero, Oaxaca. \\
\hline Yucatán Peninsula & Campeche, Quintana Roo, Yucatán. \\
\hline
\end{tabular}

Source: Own elaboration with information from Bassols (1992).

Table 7 shows summary statistics by region. There are no substantial differences in average age, education, and tenure; however, there are significant differences across regions on average wages. The lowest average salary is in the south, where the mean wage is 5,850, whereas the highest one is in the northwest, with 8,145 as the mean wage. 
Table 7: Summary statistics by region

\begin{tabular}{lcccc}
\hline Region & Wage & Age & Education & Tenure \\
\hline Northwest & $\$ 8,145.00$ & 38 & 10 & 8 \\
North & $\$ 7,093.00$ & 38 & 10 & 8 \\
Northeast & $\$ 7,874.00$ & 38 & 10 & 7 \\
Center-west & $\$ 6,977.00$ & 37 & 9 & 7 \\
Center-east & $\$ 6,588.00$ & 38 & 9 & 8 \\
East & $\$ 7,196.00$ & 39 & 10 & 9 \\
South & $\$ 5,850.00$ & 39 & 9 & 9 \\
Yucatán Peninsula & $\$ 6,875.00$ & 38 & 9 & 8 \\
\hline
\end{tabular}

Source: Own elaboration with data from INEGI, 2005-2018.

\section{EMPIRICAL ANALYSIS}

To carry out the econometric analysis, we perform the regression through Ordinary Least Squares (OLS). We present a fraction of the estimating results that correspond with the workers' characteristics in table 8 . We omitted some variables in this table because they correspond to interaction ter$\mathrm{ms}$; thus, rather than directly interpreting the output regression, it is more valuable and interesting to analyze the average marginal effect.

We should avoid directly interpreting some coefficients from Table 8 , like female or education, because the variables associated with them interact with other independent variables. The coefficient of age may be interpreted directly from Table 8 , although we must consider the square form. In this case, the impact of age on wage is 0.047 , which means that for every year that the worker gets old, wage increases 4.7 per cent; nevertheless, this increment is not unlimited; when a worker reaches 48 years old, the salary reaches its maximum level, thereafter, it starts to narrow. This effect is also related to the experience because experience and age are strongly correlated. 
Table 8: Estimating results of regression (2)

\begin{tabular}{lr}
\hline Variables & $\log (\mathrm{WAGE})$ \\
\hline Age & $0.048^{* * *}$ \\
$\mathrm{Age}^{2}$ & $(0.001)$ \\
Female & $-0.0005^{* * *}$ \\
& $(0.000)$ \\
Married & $-0.130 * *$ \\
& $(0.055)$ \\
Female*Married & $0.177 * * *$ \\
Tenure & $(0.006)$ \\
& $-0.265 * * *$ \\
Education & $(0.011)$ \\
Female*Education & $0.006 * * *$ \\
& $(0.001)$ \\
Constant & $0.053 * * *$ \\
& $(0.004)$ \\
& $0.013 * * *$ \\
& $(0.002)$
\end{tabular}

Other controls (explained below)

Observations

$1^{\prime} 809,288$

R-squared

0.385

Cluster-robust standard errors in parenthesis.

$* * * \mathrm{p}<0.01, * * \mathrm{p}<0.05, * \mathrm{p}<0.1$

On average, there is significant evidence about the differences in wages between women and men. Women earn, on average, 13 per cent less than men, without considering the economic activity, region, or years of education.

About the marital status, the coefficient of married corresponds to men workers; this means that men married earn 17 per cent more than men non-married. On the other hand, married women earn 9 per cent less than non-married men. Moreover, tenure adds 0.6 per cent to the wage for every additional year in the current job. 
According to these results, the education return on wages is 1.3 per cent higher for women. However, we should take this affirmation carefully because the distribution of women workers on activities is so far unknown. Perhaps, women with high education levels are employed in very profitable jobs, even though these women are a minority. We know that, on average, women earn less than men (around 13 per cent), and the bulk of women may employ in low-profitable jobs, which drags the average wage of women narrow.

To extend the analysis, the interpreting of the interaction terms is through an average marginal effect. In the following Figure 1, we show the average marginal effect of females on economic activity. It shows that construction is the economic activity that narrows the gap between women's and men's wages; in this activity, women earn 8 per cent less than men. This difference is statistically significant at 1 per cent, whereas commerce and miscellaneous services sharp this gap. Women working as laborers in construction activities should be scarce. Instead, women engage in management and office activities in the construction sector. They require more skills and education, which explains a lower wage difference among men and women in this activity.

Furthermore, in commerce and miscellaneous services, the gap in wages is 51 per cent and 40 per cent, respectively, between women and men; these differences are statistically significant at 1 per cent.

Women earn less than men in all regions, too; as shown in Figure 2, the region with the highest difference in wage between women and men is the Yucatan peninsula, where women earn 45.6 per cent less than men workers statistically significant at 1 per cent. However, we found that the confidence interval is more prominent than in the other regions. After Yucatan Peninsula are the southern and eastern regions where differences in wages between women and men are 36.6 per cent and 35.5 per cent, respectively, significant at 1 per cent. On the other hand, we find the lowest difference in wages between women and men in the north, in this region, women earn 30 per cent less than men. Even though this difference is the lowest in the country, it is still big and statistically significant.

In Figure 3, is shown the average marginal effects of education by economic activity; in other words, it is the education return on wage by economic activity. The highest return is in the professional services, about 8.4 per cent, and statistically significant at 1 per cent. Jobs in this sector are known as white-collar jobs. 


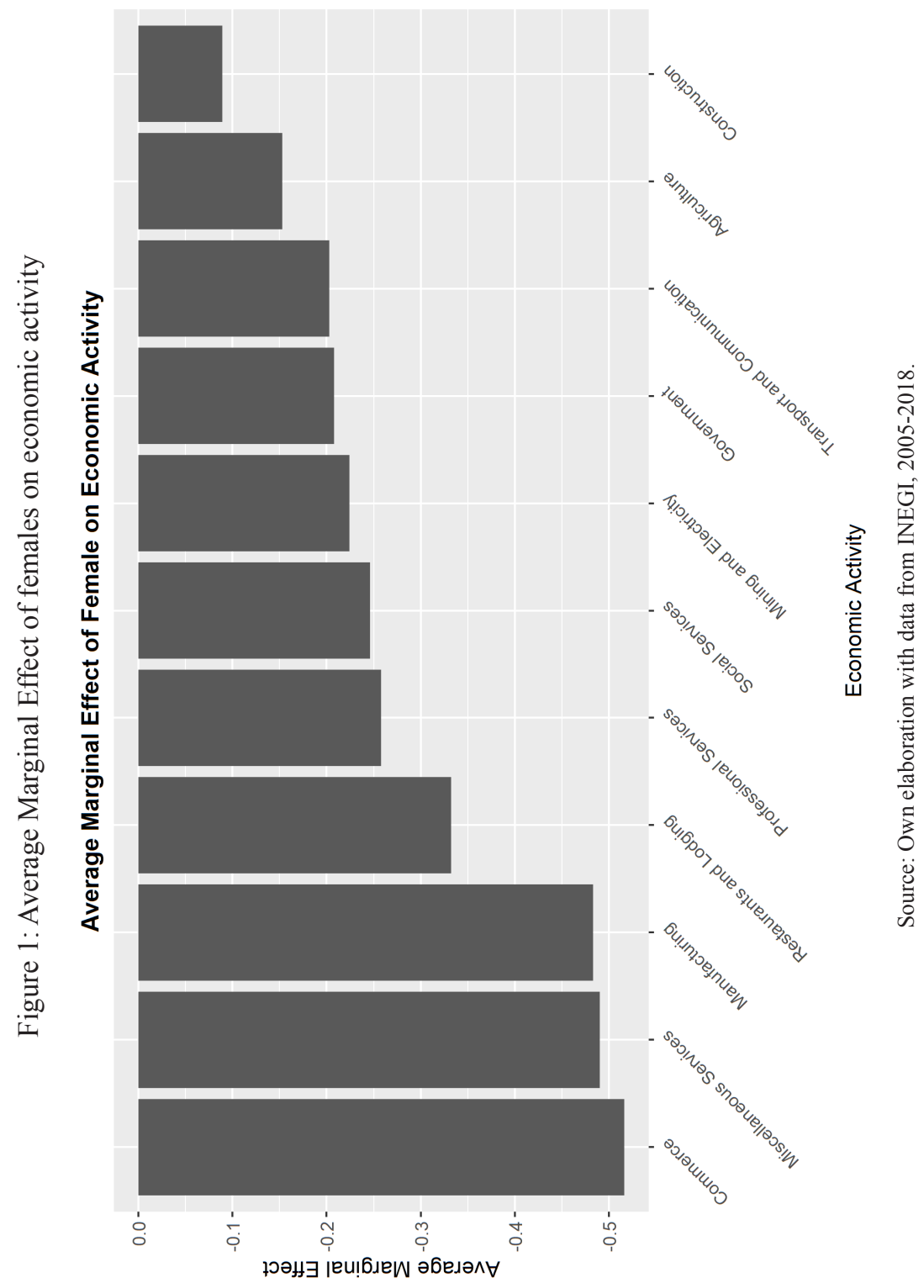


The sectoral-regional structure of the wages in Mexico / R. I. VALDEZ y V. SOBREVILLA

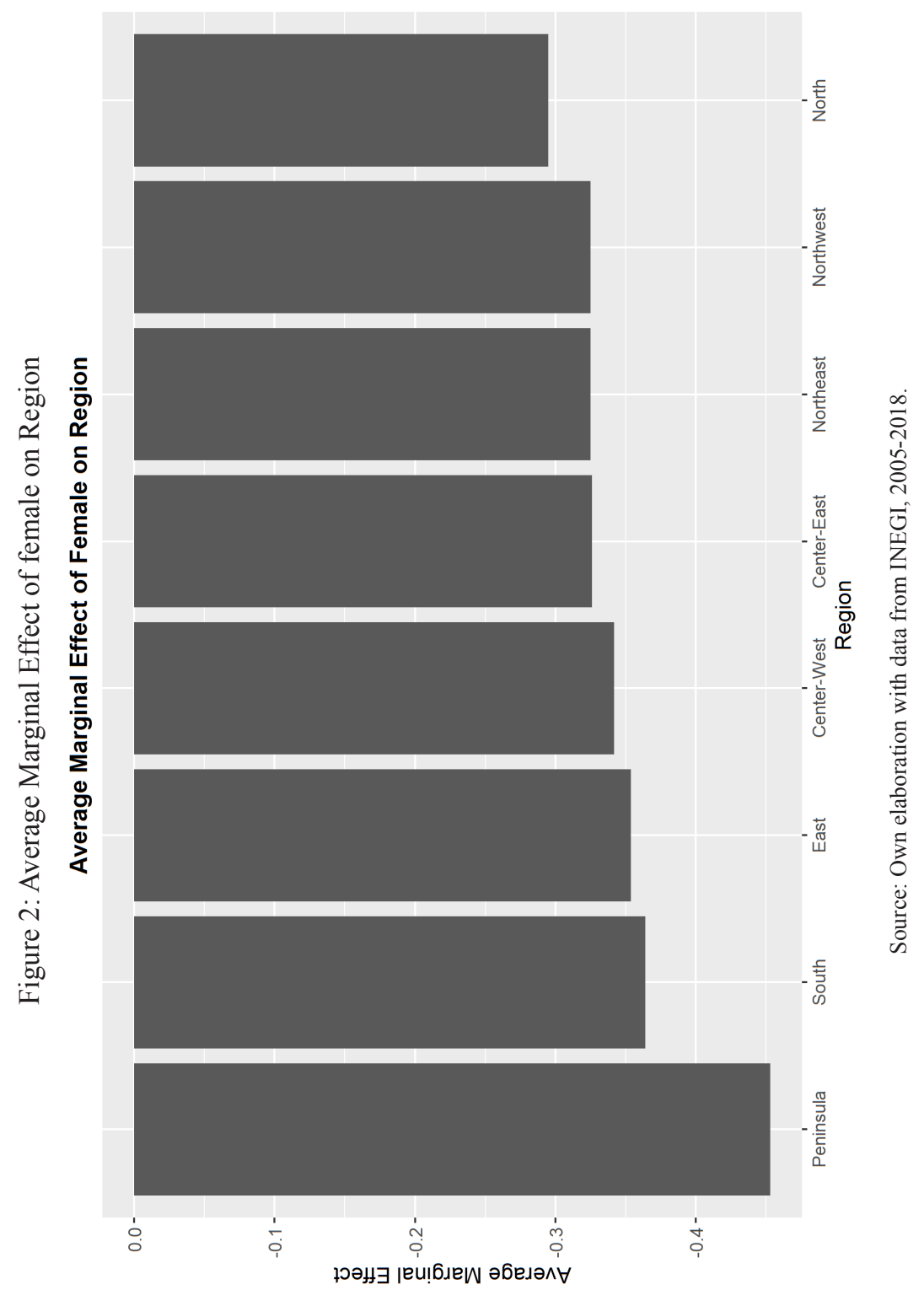




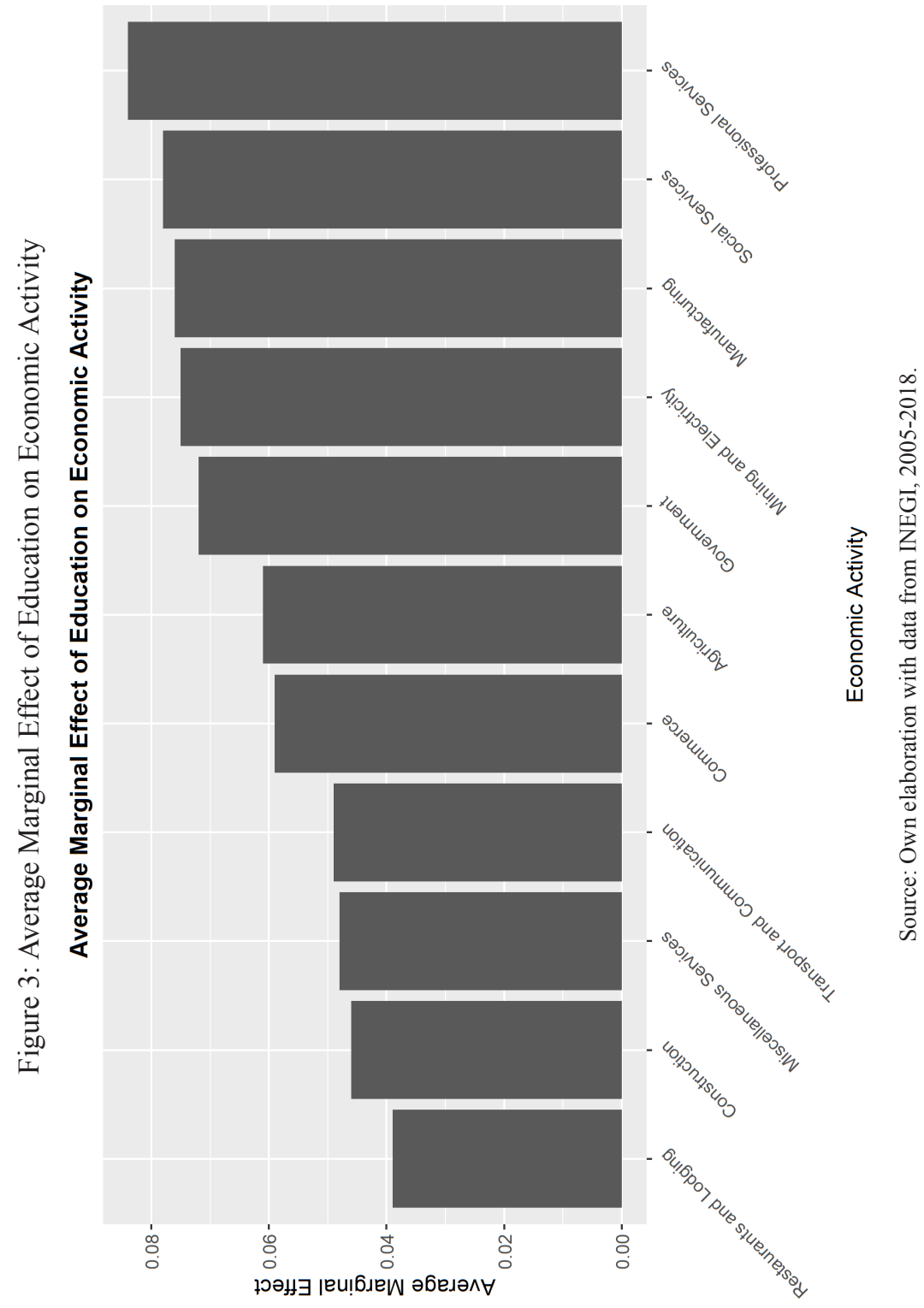


The sectoral-regional structure of the wages in Mexico / R. I. VALDEZ y V. SOBREVILLA

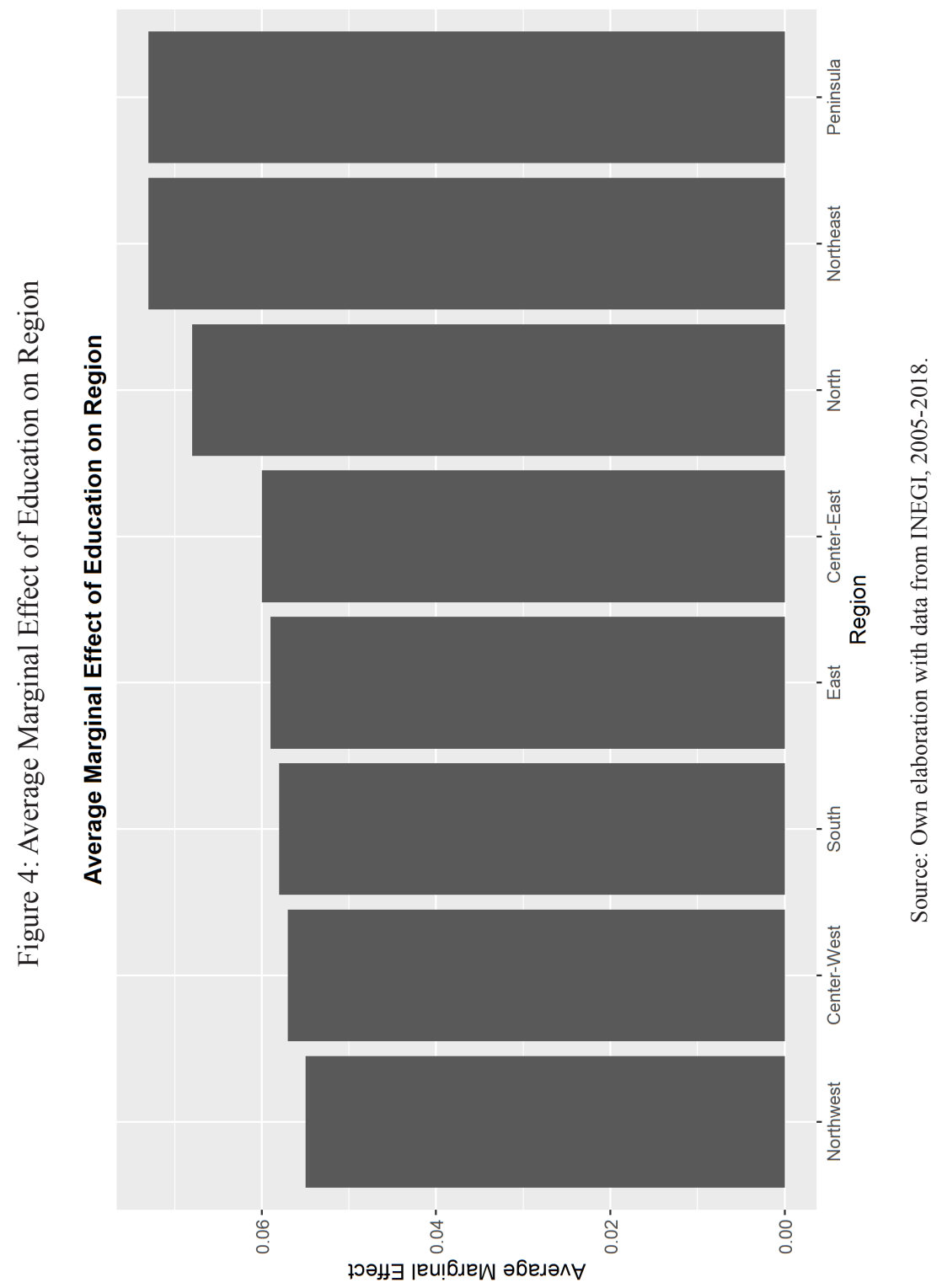



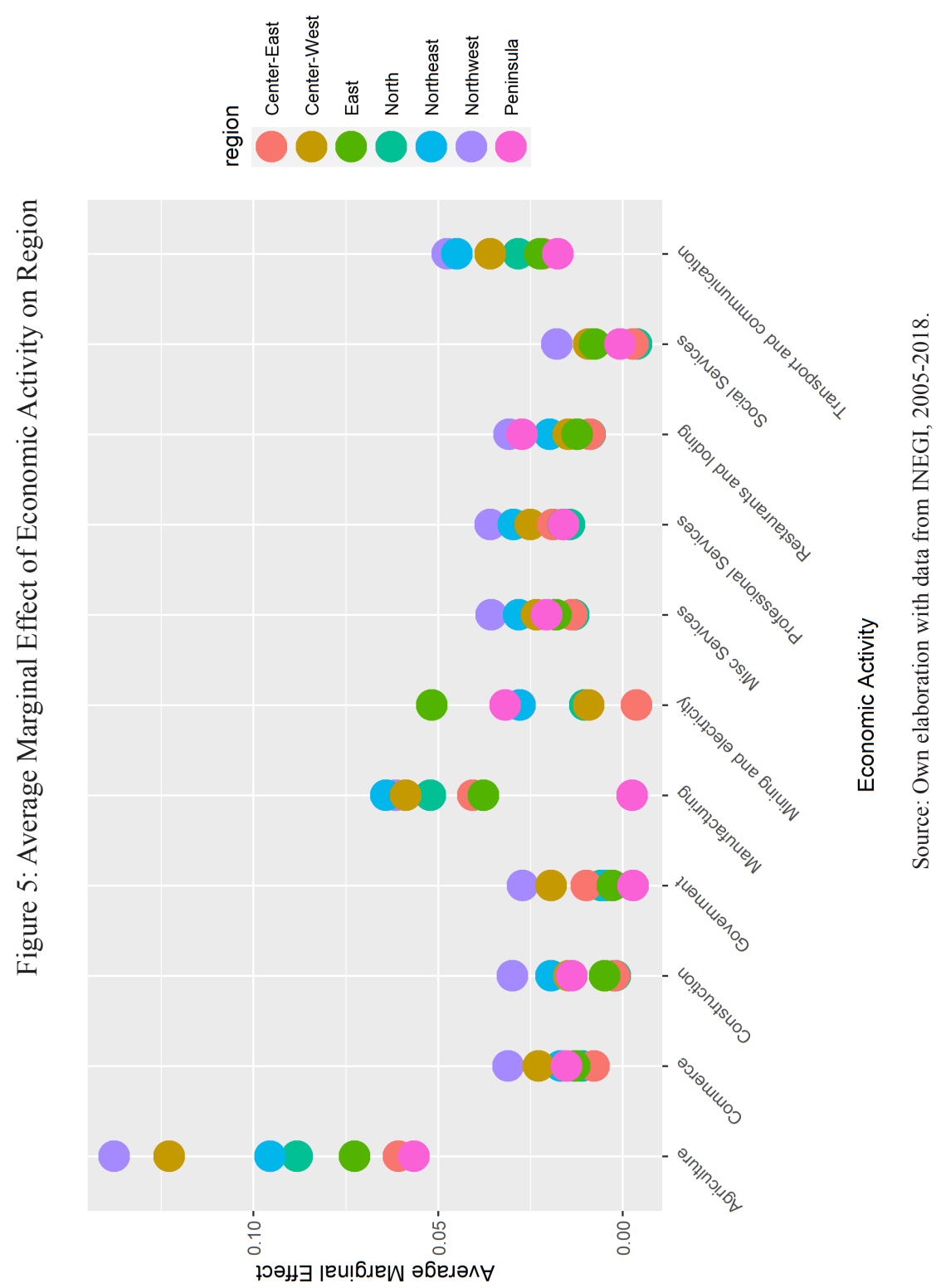
These jobs demand high-skilled and high-educated workers; this explains the highest education return on salaries, contrary to the restaurants and lodging services, where the education return is 3.9 per cent, half of the return in professional services. Restaurants and lodging services not necessarily demand high-educated workers; thus, education in this sector is irrelevant. The same is valid for construction activities; most workers in this activity do not need high education, explaining the return of 4.6 per cent.

The highest education return on wage is in the northeast and Yucatan peninsula; it is 7.3 per cent for each additional year of education. However, the confidence interval for the last is considerably wide. Education in the northwest and center-west has the lowest return on wage, 5.5 per cent, and 5.7 per cent. Previously, we addressed that in the Yucatan peninsula is the most significant difference between women and men salaries; moreover, in general, education is slightly more profitable for women; however, in the Yucatan peninsula, women earn significantly less than men, no matter the years of schooling (Figure 4).

Finally, we show the economic activities return on wage by region in Figure 5. The average marginal effects take the south region as the base. We find the most significant wage differences in agriculture; this activity is 100 per cent more profitable in the northwest and the center-west than in the south; in other words, agricultural wages in the northwest and the center-west doubles the southern ones. Also, the south, along with the Yucatan Peninsula are backward regarding manufacturing wages. In contrast, the salary in the northeast in manufacturing is 50 per cent higher than in the southern manufacturing. The rest of the activities are slightly well paid in other regions.

\section{Concluding Remarks}

The results shown above reflect a heterogeneous structure of wages in Mexico as sectoral as well as regional. There are several spots where we may conduct the analysis and conclusions. About gender, we found rough wage discrimination against females. Women earn less than men independently on the economic activity or the region where they work. Overall, this result constitutes a national problem that should concern all because the wages in the same economic activity and the same region should not differ sharply. On average, women own more years of education than men, and both sexes report the same amount of experience. 
The wage differences between them are hardly attributable to the productivity difference rates; thus, we show that the wage gap between women and men is evidence of significant wage discrimination against women.

Education seems more profitable for women than for men; this constitutes an essential element for reducing the gap between females' and males' wages. However, it is necessary to know the women's distribution in a specific economic activity and their job positions. It is still unknown whether education is more profitable because their duty is different from men's. A new investigation should stress the hypothesis about the wage gap between sexes in the same responsibilities and tasks.

There are differences in wages among regions; however, the productivity rates between regions are different, and the economic theory suggests these explain the gap between salaries. In this case, there is a clear backward region, the southern one, whose activities are less paid than in other regions. The fact that the same economic activity, like agriculture, is better paid in the north than in the south provokes a migration phenomenon. Whether a worker knows that would earn more in other regions for the same activity, would migrate. Usually, the best workers in terms of age, education, and skills tend to relocate to reach better conditions to live. This phenomenon increases the gap between backward and forward regions.

Another critical element that could help narrow the gap between women's and men's wages is the strengthening of unions. Before 1996, unions tended to equalize the forces affecting the dispersion of wages (Fairris, 2003). The strength of unions is critical for the defense of the workers; however, in countries underdeveloped like Mexico, with a weak justice system, unions represent a barrier for the flow of investment and a risk for the defense of private property.

\section{REFERENCES}

Ahamdanech Zarco, Ismael, García Pérez, Carmelo, and Simón Pérez, Hipólito, 2011, "La desigualdad de los salarios en España: una perspectiva regional", in $\mathrm{Mo}$ neda y Crédito, (231), pp. 53-93. Available at https://bit.ly/33VMapC, consulted in $17 / 05 / 2021$.

Airola, Jim, and Chinhui, Juhn, 2005, Wage Inequality in Post-Reform Mexico. 1525. Bonn. Available at https://bit.ly/2RhqxO9, consulted in 2/01/2021.

Aláez, Ricardo, Longás, Juan Carlos, and Ullibarri, Miren, 2003, "Diferencias salariales en España: un análisis sectorial/regional", in Investigaciones Regionales - Journal of Regional Research, (3), pp. 5-24. Available at https://bit.ly/3wd2TRt, consulted in 17/05/2021. 
Antonczyk, Dirk, DeLeire, Thomas, and Fitzenberger, Bernd, 2010, Polarization and Rising Wage Inequality: Comparing the U.S. and Germany. 4842. Bonn: Institute for the Study of Labor. Available at https://bit.ly/3uXQtwP, consulted in 2/01/2021.

Bassols, Angel, 1992, México: Formación de Regiones Económicas. Universidad Nacional Autónoma de México. México, D.F.: Universidad Nacional Autónoma de México.

Blau, F. D., and Kahn, L. M., 1992, “The gender earnings gap: learning from international comparisons", in American Economic Review, 82(2), pp. 533-538. doi: $10.2307 / 2117457$.

Buchinsky, Moshe, 1994, "Changes in the U. Wage Structure 1963-1987: Application of Quantile Regression", in Econometrica, 62(2), pp. 405-458. Available at https://bit.ly/2Qv0DGe, consulted in 17/05/2021.

Cabrera, Claudio, Mungaray, Alejandro, Varela Llamas, Rogelio, and Hernández, Emilio, 2008, "Capital humano e ingresos en la manufactura de Tijuana y Mexicali, 1994-2001", in Estudios Fronterizos, 9(18), pp. 95-114. Available at https:// bit.ly/3eVp5Kk, consulted in 2/01/2021.

Cardoso-Vargas, Carlos Enrique, 2016, "Desigualdad salarial y potencial de mercado. Evidencia para México", in El Trimestre Económico, 83(329), pp. 185-220. Available at https://bit.ly/3wcZHW3, consulted in 2/01/2021.

Carrillo-Huerta, Mario M., and Vázquez Mateos, Haydee V., 2005, "Desigualdad y polarización en la distribución del ingreso salarial en México", in Problemas del Desarrollo, 36(141), pp. 110-130. Available at https://bit.ly/33RQXsm, consulted in $2 / 01 / 2021$.

Castro Lugo, David, and Morales Sandoval, Berenice, 2011, "Changes In Regional Wage Inequality in Mexico, 1994-2003”, in Frontera Norte, 23(45), pp. 35-66.

Cortez Yactayo, Willy Walter, 2005, "Dispersión y estabilidad de las diferencias salariales interestatales en México, 1984-2000", in Investigación Económica, 64(253), pp. 123-158. Available at https://bit.ly/3tPy4AU, consulted in $17 / 05 / 2021$.

Esquivel, Gerardo,1999, "Convergencia regional en México, 1940-1995", in Trimestre Economico, 66(4), pp. 725-761. Available at http://www.jstor.org/stable/20857005.

Fairris, David, 2003, "Unions and Wage Inequality in Mexico", in ILR Review, 56(3), pp. 481-497. doi: 10.1177/001979390305600307.

Groot, Stefan P.T., de Groot, Henri L.F., and Smit, Martijn J., 2014, "Regional wage differences in the netherlands: Micro evidence on agglomeration externalities", in Journal of Regional Science, 54(3), pp. 503-523. doi: 10.1111/jors.12070.

Juhn, C., Murphy, K. M., and Pierce, B., 1993, "Wage inequality and the rise in returns to skill", in Journal of Political Economy, 101(3), pp. 410-442. doi: $10.1086 / 261881$. 
Katz, David H., Lawrence, F., and Kearney, Melissa S., 2008, "Trends in U.S. wage inequality: Revising the revisionists", in Review of Economics and Statistics, 90(2), pp. 300-323. doi: 10.1162/rest.90.2.300.

Kuznets, Simon, 1955, "Economic Growth and Income Inequality”, in The American Economic Review, 45(1), pp. 1-28. doi: 10.2307/2220605.

Madariaga, Rafa, Martori, Joan Carles, and Oller, Ramon, 2012, "Distribución espacial y desigualdad de la renta salarial en el Área Metropolitana de Barcelona”, in Scripta Nova: revista electrónica de geografía y ciencias sociales, 16. Available at https://bit.ly/3bwTIDu, consulted in 17/05/ 2021.

Mincer, Jacob, 1974, Schooling, experience, and earnings. New York: National Bureau of Economic Research and Columbia University.

Monastiriotis, Vassilis, 2003, "Individual inequalities and regional disparities in the UK: convergence, asymmetries and spatial dependence", in Hardy, Sally, Bibby Larsen, Lisa, and House, Fiona (eds) Economic Governance Post-Devolution: Differentiation of Convergence? Seaford: Regional Studies Association, pp. 87-91.

Palacio Morena, Juan Ignacio, and Simón Pérez, Hipólito, 2004, "Dispersión salarial entre establecimientos y desigualdad salarial", in Revista de Economía Aplicada, 12(36), pp. 47-82. Available at https://bit.ly/3hxS0Wl, consulted in $17 / 05 / 2021$.

Plascencia López, Ismael, 2009, “Liberalización económica y desigualdad salarial en 12 áreas urbanas de México, 1987-2002: la hipótesis de la "U" invertida de Kuznets", in Región y Sociedad, 21(44), pp. 10-42. Available at https://bit.ly/3eVgBmd, consulted in 17/05/2021.

Popli, Gurleen K., 2011, "Changes in Human Capital and Wage Inequality in Mexico", in Oxford Development Studies, 39(3), pp. 369-387. doi: https://doi.org /10.1080/13600818.2011.596276.

Rodríguez, Reyna, 2018, "Brecha salarial por género en México: desde un enfoque regional, según su exposición a la apertura comercial 2005-2015”, in Noésis. Revista de Ciencias Sociales y Humanidades, 27(54). doi: https://dx.doi. org/10.20983/noesis.2018.2.2.

Rodríguez, Reyna, Huesca Reynoso, Luis, and Camberos Castro, Mario, 2011, "Mercado laboral, inequidad salarial y cambio tecnológico regional", in Frontera Norte, 23(45), pp. 7-33. Available at https://bit.ly/3uYb8AH, consulted in $17 / 05 / 2021$.

Varela Llamas, Rogelio, Ocegueda Hernández, Juan Manuel, Castillo-Ponce, Ramón, and Huber Bernal, Gerardo, 2010, "Determinantes de los ingresos salariales en México: una perspectiva de capital humano", in Región y Sociedad, 22(49), pp. 117-142. Available at https://bit.ly/3ykFJuf, consulted in 17/05/2021.

Varela Llamas, Rogelio, and Urciaga García, José, 2012, "Diferencias salariales en México: una perspectiva de educación y actividad económica", in Revista de 
la Educación Superior, 41(162), pp. 25-43. Available at https://bit.ly/3wjRz6p, consulted in 17/05/2021.

\section{RESUMEN CURRICULAR DE LOS AUTORES}

\section{Rolando I. Valdez}

Master in Economics by the B. Autonomous University of Puebla, Doctor in Economic Sciences by the Autonomous University of Baja California. $\mathrm{He}$ is a member level C of the Researchers' National System. He is currently a Professor-Researcher of the Regional Studies Laboratory of the Faculty of Commerce and Management Victoria of the Autonomous University of Tamaulipas, and a visiting professor of the Anahuac Online University. His most recent publications are: Determinants on the newborn firms'scale in the states of Mexico: A panel data analysis" (coauthoring with Gerardo Delgado), and "Spatial diffusion of economic growth and externalities in Mexico".

Email: rivaldez@uat.edu.mx

ORCID: https://orcid.org/0000-0002-1491-305X

Verónica Sobrevilla

Master in Economic Sciences by the Autonomous University of Baja California, and Doctoral Candidate by the same University. She is a professor of the Higher Studies Institute of Tamaulipas, and Mexico's Valley University. She has performed as a public policy evaluator for the Coneval and the SHCP. Currently, she has a publication in progress named Wage inequality in Mexico: a sectoral and regional approach through a quantile regression.

Email: veronica.sobrevilla@gmail.com

ORCID: https://orcid.org/0000-0002-3059-5872 